\title{
European Motor Vehicle Manufacturers' CSR Trends - The Effect of the Emission Scandal
}

\author{
Melinda Majláth ${ }^{1}$, Pascal Ricordel ${ }^{2}$ \\ ${ }^{1}$ Óbuda University, Bécsi út 96/b, 1034 Budapest, Hungary, \\ majlath.melinda@kgk.uni-obuda.hu \\ ${ }^{2}$ Université Le Havre-Normandie, 25 rue Philippe Lebon, 76600 Le Havre, \\ France, pascal.ricordel@univ-lehavre.fr
}

\begin{abstract}
The Automotive industry plays an important role in the European economy, however, it is also responsible for environmental pollution - by manufacturing and during the lifetime of the vehicles. To decrease air pollution, industrialized countries determine stricter regulations for carmakers. In addition, those consumers who want to be environmentally conscious, are seeking "greener" cars. Unfortunately, the "Volkswagen scandal" in 2015, drew attention to the unfair behavior of car manufacturers and to greenwashing. The rising trend toward corporate social responsibility and stricter regulation policies have put pressure on the automotive industry. This article concentrates on the corporate social responsibility practices of car manufacturers, following the $V W$ cheating software scandal, in order to identify which elements of their CSR policy have been strengthened. The research investigates how the emphasis on the different elements of CSR activities has changed following the VW scandal. To answer the question, a quantitative analysis is made on the CSR data of 15 companies ( 7 from Germany, 2 from Italy, 2 from Sweden, 3 from France and 1 from the UK), whose primary industry is motor vehicle manufacturing in Europe and CSRHub provides detailed information on them. The analysis examines how the ratings of these companies has changed in the four main categories of CSR (namely: Community, Employees, Environment and Governance) during the period of 2011-2019, which can be sub-divided into two periods: 4 years before and 4 years after the scandal. The analysis shows that VW's overall CSR rating has decreased for the period of 2015-2019. Results also indicate - contrary to expectations, that Volkswagen could not improve its CSR-ratings for Product and for Environment subcategories, after the scandal.
\end{abstract}

Keywords: automotive industry; CSR; emission scandal 


\section{Introduction}

Global warming has been identified as the most frightening global environmental problem, and its causes can be traced back to the agriculture, deforestation and fossil fuel combustion [1].

Among the sources of greenhouse gases, transportation is responsible for nearly one-third of the EU's total $\mathrm{CO}_{2}$ emissions, and almost three-quarter of it comes from road transportation [2]. Based on the data from 2016, 60.7\% of it is generated by passenger cars, $11.9 \%$ by light-duty trucks, and $26.2 \%$ by heavyduty trucks [2]. Intentions are clear in the EU to decrease the emission of greenhouse gases. Energy, residential and agricultural sectors have cut emissions back since 1990, but as more people become more mobile, $\mathrm{CO}_{2}$ emissions from transport are increasing. Another reason is that newly registered cars emitted on average 0.4 grams of $\mathrm{CO}_{2}$ per kilometer more in 2017 than in 2016. EU wants to turn this trend into a positive direction and introduces new $\mathrm{CO}_{2}$ emission targets for new cars and vans [2]

About 181,000 people, worldwide, died prematurely in 2015 due to air pollution from vehicle exhaust (mainly PM2.5 and ozone) coming from diesel engines, according to a study published by ICCT (The International Council on Clean Transportation) in February 2019 [3]. The most effected countries are France, Germany, Italy and India, as most vehicles are diesel-powered. Diesel pollution would cost for EU taxpayers nearly 56 billion euros in health and non-health related expenses. This was more than five times the amount of petrol pollution costs [4].

However, the automotive companies have significant positive contribution to the economy and to the society as well. Automotive industry plays an important role in the European economy: the turnover of it represents approximately $7 \%$ of the EU GDP and the full vertical value-chain provides work for almost 14 million people, and motor vehicles account for $€ 428$ billion in taxes in the EU15 countries alone [5]. Therefore, it is a social interest that car manufacturers continue their business but with respect to society goals and needs.

Unfortunately, the Volkswagen scandal in 2015 showed that tighter regulation does not necessarily lead to positive change. The Volkswagen scandal (also called Dieselgate) reflects to the deliberate misleading action of Volkswagen: Volkswagen Group of America has developed and installed emissions control system 'defeat devices' (software) in model year 2009-2015 vehicles with 2.0 liter diesel engines. Defeat software was designed to detect when emissions tests were being run and turn on pollution controls so that a vehicle can meet air quality standards. During normal road use, the pollution controls are disabled to enhance engine performance and fuel economy, but these changes also increase emissions, of nitrogen oxides (NOx) for example. On-road emissions testing suggests that in- 
use NOx emissions for these vehicles are a factor of 10x to 40x above the EPA standard [6].

In September 2015, Volkswagen officially announced that it had falsified emissions from diesel engines and exceeded the limit by 40-50 times. Later on, Audi and Porsche were also accused for such a misleading behavior. Sources [7] point out that VW cheating behavior was not the first one in the automotive industry. Moreover, some scandals happened afterwards at Fiat Chrysler, Nissan and Daimler. In addition, since 2016, 38 out of 40 diesel cars tested by ADAC failed an NOx-test [8].

Consequently, Volkswagen has recalled 11 million cars worldwide - a majority of the recalls in the EU - and was also heavily fined. Company director Martin Winterkorn resigned after the scandal, but consistently denied knowing anything about cheating on the measurement. Criminally, only James Liang, an engineer was convicted and sentenced to 40 months in prison [9]. Later, in 2017 Oliver Schmidt, the company's CEO of the U.S. division was sentenced to 7 years in prison with a $\$ 400,000$ sentence. In the wake of the scandal, an investigation was launched in addition to Opel and for some Daimler and BMW models. On October 19, 2018, nearly 100,000 Opel were recalled as the manufacturer cheated on the Insignia, Cascada and Zafira models with Euro 6 environmental rating [9].

That highlight the confirmation of the suspicion that maybe not only VW cheated but other companies followed a similar practice. These events question the credibility of big car manufacturers, and we can ask, how honest the green initiatives of these companies are and whether they continue a real dialog with the stakeholders or not. As Corporate Social Responsibility is a complex phenomenon, we need to analyze CSR actions in a broader perspective - both in time and in space, therefore, in this study we included other car-manufacture companies and a time series of data to understand the processes.

The aims of this study are:

(1) Examine the CSR activity of Volkswagen in details before and after the scandal in comparison with the industry average.

(2) Analyze the evolution of different subgroups of CSR activity by time for Volkswagen.

The structure of this study is the following: Section 2 provides literature background for hypotheses; Section 3 describes the methodology and data sources; Section 4 introduces the empirical results and Section 5 summarizes the conclusions. 


\section{Literature Review}

The European Commission [10] defined CSR as "the responsibility of enterprises for their impacts on society". This wording has interrupted with the previous definition in which CSR was a 'volunteer' action of the companies. Nowadays there is more pressure on bigger companies to share information on their socially responsible behavior, and therefore realize real contribution to social goals. In the European Union, the importance of Corporate Social Responsibility reporting is increasing, because 2017 is the year in which the CSR reporting of large companies passes from the voluntary, to the mandatory stage, according to the requirements of the European Directive 2014/95/EU [11].

Stakeholder theory [12] emphasizes that a socially responsible company pays attention simultaneously, to the interests of all stakeholders. A socially responsible firm needs to identify these stakeholders, analyze their interests and examine them from different aspects: mainly their power and interests. Automotive industry has lots of different stakeholders: dealer/retailer, insurance companies, car owners and lenders, fleet management companies, car-sharing passengers, academia, telecom and tech companies, independent repair shops, after-market, government and public organizations, recycling companies, financial institutions [13]. The whole industry has significant role in the economic growth, on labor market and in environmental pollution - directly and indirectly. Surprisingly, even the latest studies do not mention the natural environment as one of the stakeholders of the automotive industry [13].

The growing number of CSR literature, makes it possible to create subgroups of studies and concentrate at a higher level on given topics or areas. One obvious subgroup of literature is based on the geographical criteria while another one divides the groups according to the industries of the companies. Geographical criteria may reflect to legal or cultural peculiarities.

More researcher argue that industry-specific analysis can lead to higher internal validation of models and more precise conclusions because special sectorial conditions, different legislations, the given market structure have significant effect on relative importance of elements of CSR policy and the actual performance of the companies in these areas [14]. Dabic et al. [15] also emphasize that each sector has its special rules, norms, practices and trends. Social problems and public scandals turned attention to petroleum, financial and textile industries, while essential consumer needs highlighted the CSR actions of food, beverage and pharmaceutical sectors.

Tarabella and Burchi [16] tried to identify the main economic benefits from CSR activities that are more relevant for the chemical industry - assuming that only CSR activities related to environmental management improve economic and financial performance of chemical firms, not global CSR strategy. They also analyzed the sector-specific dimensions of CSR, which have the greatest effects 
on business performance of chemical companies. They found evidence to support their hypothesis, namely that environmental initiatives effectively improve economic results of these firms.

Russo-Spena, Tregua and De Chiara [17] analyzed automotive industry firms' disclosure practices in a longitudinal study, focusing on the period of 2010-2014. Their focus was on the reporting activity itself, while this article focuses on the CSR performance of the automotive firms. The base sample consisted of 26 firms, but later only 15 companies had enough data for the analysis. Automotive firms payed the most attention to environmental issues, to community issues and labor practices, and with an increasing trend between 2010-2012, however, community issues and labor practices have lost a bit from their citation rate in the following years.

They found that automotive firms showed an increased intention to report on environmental and social issues and they tried to harmonize and standardize their reports - due to the normative pressure. In line with other studies [18], RussoSpena et al. [17] identified environmental issues as the most prominent topic in CSR reports of motor vehicle manufacturers.

Teck et al. [19] examined the organizational change and moral transpose of the Diesel Gate. Their study shows that VW applied a triple bottom line positivistic approach before the scandal, but it showed a gradual recession of ethical values over time and had a peek when their scandal exposed in 2015, therefore, VW experienced an ethical dissonance between their idealized and realized values and behavior. VW then engaged in a reflexive organizational change with refreshing their business ethics commitment. The authors think that VW materializes a higher level of CSR after the crisis.

Based on this logic and based on the expectation on the society, we can formulate our first (alternative) hypothesis:

H11: VW's CSR activity and its rating has changed positively following the Diesel Scandal in 2015.

Analyzing only the CSR reports of firms could be misleading, because firms report intentions more than real actions and performance. Reporting standards, like GRI can help to make CSR reports more transparent and comparable to each other.

In the critical view of CSR, there is a going debate on whether CSR is just a public relation activity of the companies which tries to minimize the risk [20] or it is proactive action which is integrated into the strategy of companies [21].

Supposing that VW shows a real engagement toward social goals and the cleaner future, the firm should focus more on the environmental issues related to its activity. Moreover, as the scandal focus was on the product features, the company 
should take big steps in improving its product features. Therefore, the second alternative hypothesis is the following:

H12: Significant positive change can be experienced at the "Environment" and "Product" aspects among VW's CSR activities after the scandal.

\section{Methodology}

Based on the focus of this study, our aim was to use a complex measurement of CSR activity, which can be subdivided into different areas. Among existing aggregated measures, we chose CSRHub database based on three main reasons: (1) systematic and broad data collection; (2) time series of data; (3) quantitative, comparable measurements for the subcategories of CSR. CSRHub has been gathering information systematically on companies' CSR activity and they use multiple sources to collect data. CSRHub relies on broad variety of data sources: sustainability reports, sustainability indices (MSCI, VigeoEiris), media, (like Newsweek, Thomson Reuters), sources focusing on given topic (Glassdoor, Clean Clothes Accord). Moreover, distinct sources track different group of companies, because there are industry or country specific sources. CSRHub has been gathering information from 2008, on a monthly basis. That makes possible to identify and analyze trends based on the data. Majority of information sources update their data only once a year - e.g. sustainability reports or awards, however not at the same time.

CSRHub unifies the data from different sources, as data can be numerical score (between 0.0-1.0 or e.g. amount of money spent on charity), can be measured on ordinal scale (from A++ to $\mathrm{C}--$ ), or can be binary data (the company is an award winner or not). They use their own weights for the data sources based on the biases identified among data coming from different sources. Then combines, all of the available data on a company and generates base ratings at the subcategory level - followed by the aggregation of these ratings to the category level.

CSRHub have categorized more than 5000 data-element into the twelve CSR subcategories. They evaluate companies' CSR performance grouped into four main categories, namely: Community, Employees, Environment and Governance (Figure 1). Each main category is divided into 3 subcategories, which helps to understand the background of the changes of the evaluation within the topics. CSRHub uses a rating scale of 0-100, which makes the comparison of companies' CSR performance within or between the industries and/or between countries/regions possible. 


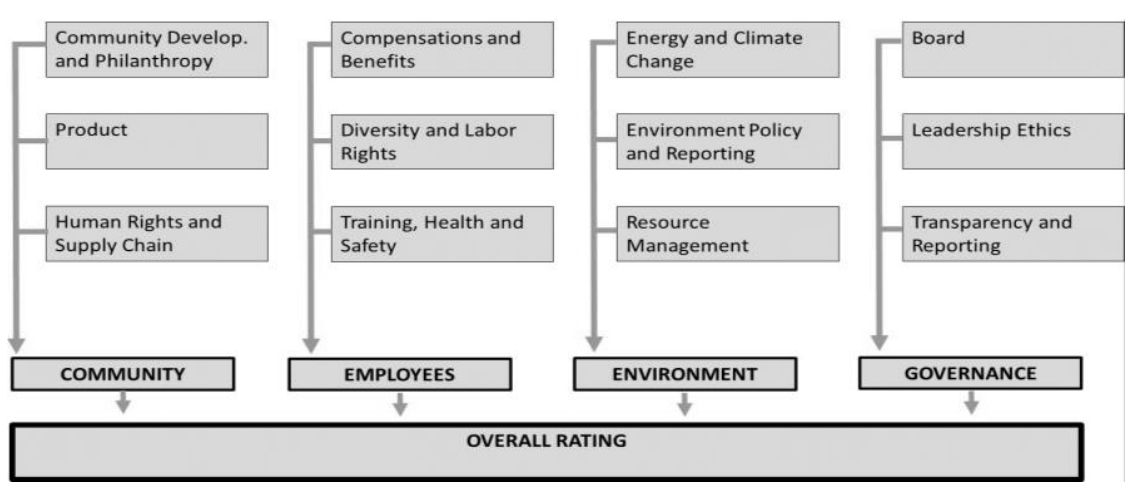

Figure 1

Description of CSRHub rating system

Source: https://esg.csrhub.com/csrhub-esg-data-schema, own illustration

From the point of view of the selected industry, it is a challenge to distinguish companies based on their countries because car manufacturers are typically multinational companies with different subsidiaries. CSRHub tries to give rating at a parent level of the company, however it acknowledges that "it is difficult to fit together sometimes conflicting ratings on a company's subsidiaries or on its products" 1 .

Data have been collected in December 2019, therefore data reflects "2019" in the research means the data from August, 2019, which was the newest data available at CSRHub in December. Also, a filter was used to select only fully rated companies and eliminate only those partially rated - in order to get a broad and full picture. However, CSRHub supports using partially rated companies in creating the country and industry average ratings, as "partially rated companies have slightly better than average scores for the area they report. Therefore, including them in our averages raises those averages slightly. We believe this makes sense. Companies tend to report their more positive information and suppress data that could make them look bad." 2 Considering this claim, industry average is also used as a benchmark in this study to highlight the differences in trends.

\subsection{Sample Description}

Data search focused on the European region, and on motor vehicle manufacturing within the durable goods category. Fifteen companies have been selected, from which 10 operates on $\mathrm{B} 2 \mathrm{C}$ markets and other five mainly relevant in $\mathrm{B} 2 \mathrm{~B}$

https://esg.csrhub.com/csrhub-ratings-methodology, retrieved 03 April 2021

https://esg.csrhub.com/partially-rated-companies, retrieved 03 April 2021 
business. Their attributes are collected in the table below (Table 1), mentioning also those special issues that are relevant from CSR point of view. Some of them are political issues (Iran or Burma involvement), some are related to social problems (child labor).

Bengtsen and Kelly [22] published that some of the world's biggest carmakers including Vauxhall, BMW, Volkswagen and Audi were accused of using minerals for car paint, which were mined in illegal mines, using child labor. Volkswagen (which owns Audi) and BMW reacted to the allegations and communicated that child labor is prohibited by their sustainability standards and is not tolerated, so they started investigations to know whether any corrective action plan is needed.

Beside the selected $\mathrm{B} 2 \mathrm{~B}$ and $\mathrm{B} 2 \mathrm{C}$ motor vehicle manufacturers, we are going to use the world industry average provided by CSRHub as a benchmark for some of the following analyses.

Table 1

Sample characteristic description of selected motor vehicle manufacturing companies from Europe based on CSRHub database Note: * provides full data from $2012 * *$ provides full data from $2015 * * *$ primary industry is machinery manufacturing in pairs with the final result

\begin{tabular}{|c|c|c|c|c|c|}
\hline $\begin{array}{l}\text { Primary } \\
\text { business } \\
\text { focus }\end{array}$ & $\begin{array}{l}\text { Motor Vehicle } \\
\text { Manufacturer }\end{array}$ & Country & $\begin{array}{l}\begin{array}{l}\text { Number } \\
\text { of total }\end{array} \\
\text { sources } \\
(2008- \\
2019) \\
\end{array}$ & $\begin{array}{l}\text { Number } \\
\text { of active } \\
\text { sources } \\
(2019)\end{array}$ & Special Issues \\
\hline \multirow{10}{*}{$\begin{array}{l}\text { B2C } \\
\text { "10 } \\
\text { European } \\
\text { Motor } \\
\text { Vehicle } \\
\text { Manu- } \\
\text { facturers" }\end{array}$} & Audi AG * & Germany & 35 & 12 & \\
\hline & BMW & Germany & 118 & 33 & \\
\hline & Daimler AG & Germany & 125 & 31 & \\
\hline & Ferrari SpA ** & Italy & 22 & 14 & Iran involved \\
\hline & Fiat Auto & Italy & 110 & 23 & \\
\hline & $\begin{array}{l}\text { Porsche } \\
\text { Automobil } \\
\text { Holding } \\
\text { Preference SE }\end{array}$ & Germany & 42 & 15 & $\begin{array}{l}\text { Burma, } \\
\text { Sudan, Iran } \\
\text { involved } \\
\text { Child labour } \\
\text { involved }\end{array}$ \\
\hline & $\begin{array}{l}\text { PSA Peugeot } \\
\text { Citroën }\end{array}$ & France & 83 & 27 & Iran involved \\
\hline & Renault SA & France & 89 & 24 & Iran involved \\
\hline & Volkswagen AG & Germany & 122 & 27 & $\begin{array}{l}\text { Child labour } \\
\text { involved }\end{array}$ \\
\hline & 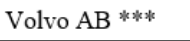 & Sweden & 93 & 38 & \\
\hline \multirow{5}{*}{$\begin{array}{l}\text { B2B } \\
\text { "5 B2B } \\
\text { Motor } \\
\text { Vehicle } \\
\text { Manu- } \\
\text { facturers" }\end{array}$} & $\begin{array}{l}\text { Autoliv Asp, } \\
\text { Inc. }\end{array}$ & Sweden & 41 & 19 & \\
\hline & $\begin{array}{l}\text { KION } \text { GROUP } \\
\mathrm{AG}^{* *}\end{array}$ & Germany & 12 & 13 & \\
\hline & Lookers PLC & $\begin{array}{l}\text { United } \\
\text { Kingdom }\end{array}$ & 16 & 8 & \\
\hline & Plastic Omnium & France & 25 & 9 & \\
\hline & Rheinmetall AG & Germany & 27 & 11 & $\begin{array}{l}\text { Labour unions } \\
\text { supporter }\end{array}$ \\
\hline
\end{tabular}

Source: CSRHub database, own compilation 


\section{Results}

\subsection{Overall CSR Rating of B2C and B2B European Motor Vehicle Manufacturers}

In the first phase of the analysis, we calculated the $10 \mathrm{~B} 2 \mathrm{C}$ and the $5 \mathrm{~B} 2 \mathrm{~B}$ motor vehicle manufacturers' overall CSR ratings for the 2011-2019 period. This period shows 4 years before and after the VW scandal, which is long enough to evaluate CSR trends.

The results show that B2C companies' overall CSR score is significantly higher than for B2B companies' values, but the latter shows high volatility (Figure 2). The differentiation of companies based on their main business area is relevant because those companies who operate in B2C business are more frequently engage in attention-grabbing CSR actions and better exposed to criticism of consumers or civil organizations. This probably motivates them to perform better.

Unfortunately, a slight negative trend in the overall CSR rating can be detected both for the 10 B2C carmakers and for the world industry average since 2016.

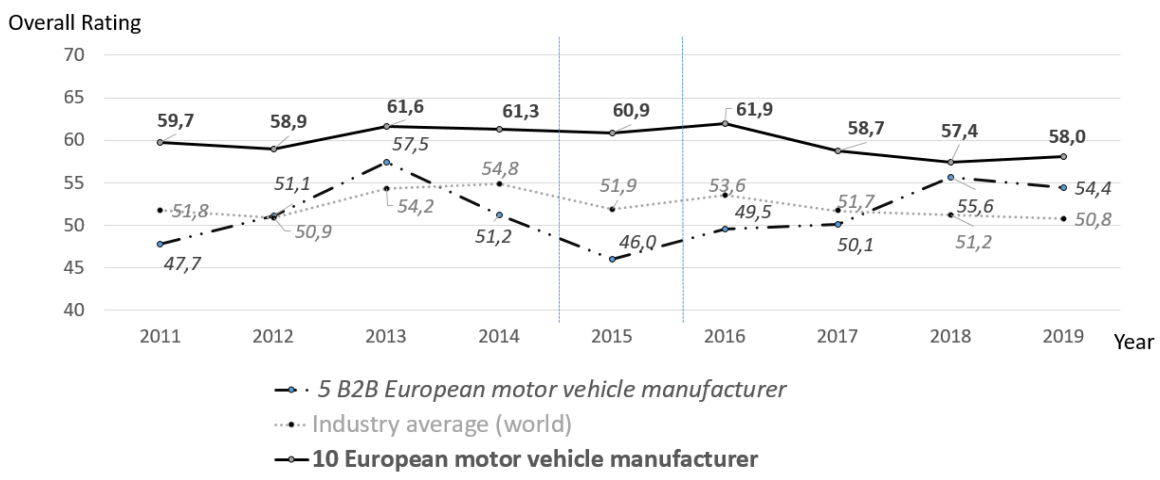

Figure 2

Overall CSR rating of European motor vehicle manufacturers in comparison with the world industry average in the period of 2011-2019

Source: own calculation from CSRHub database

The five companies, which play dominant role on the B2B market show completely different trend in their CSR performance during the examined period than the B2C firms. Concerning that difference together with the focus of the research, we have decided to concentrate on the 10 motor vehicle manufacturers whose main focus of business is $\mathrm{B} 2 \mathrm{C}$. 


\subsection{Overall CSR Rating of the 10 European Motor Vehicle Manufacturer and Volkswagen}

Volkswagen Group is a leading automobile manufacturer, and operates 61 production plants all over the world. Its product range consists of models from low-consumption small cars (Volkswagen, SEAT) to luxury high-end vehicles such as Bugatti and Lamborghini, and commercial vehicles (e.g. Scania). According to Fortune Global 500 list, Volkswagen was the largest car manufacturing company both in 2019 and in 2020 based on its revenue. These facts underline the relevance of the behavior of the market-leader, especially because it can serve as a role model to the followers.

Therefore, at the next step of the analysis, Volkswagen's overall CSR rating is compared to the CSR performance of the 10 European carmakers and to the world industry average (Figure 3). In the period of 2011-2015 VW's CSR rating was very close to the selected 10 European carmakers' average. However, following the year of the scandal, VW has been showing a negative trend in its CSR rating. Consequently, the 10 carmakers average has been also decreasing. As other car manufacturers were involved in the usage of cheating methods, the skepticism of consumers and decision makers have become stronger. The credibility-loss effected the whole automotive industry and their stakeholders.

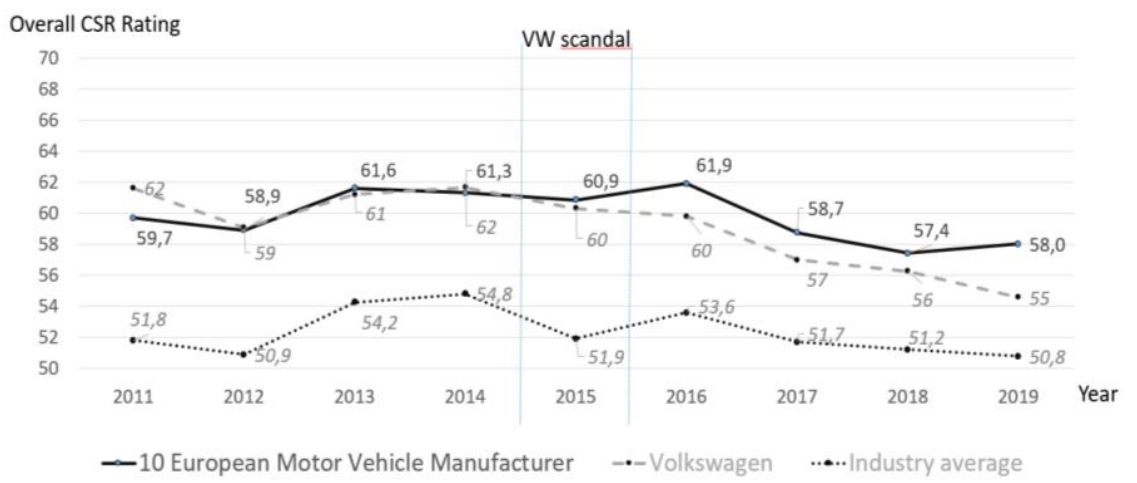

Figure 3

Overall CSR ratings of the 10 European motor vehicle manufacturers, Volkswagen and the industry average between 2011-2019

Source: own calculation from CSRHub database

The company started using the misleading software in its cars before 2011 [23], so it could communicate its business success because of its sustainable solutions for many years. It was not just one mistake, but also a deliberate, systematic, longterm practice. The major contradiction of this case, is that VW advertised itself as a leader in sustainable car making: the technology itself is named: TDI clean diesel. The greener solution was a competitive advantage of their diesel cars, 
so the incorrect behavior happened in the front line. (However, we must add that VW's performance in other areas is great and other product features are very convincing for the consumers.)

Before the scandal, VW was said to be 'the most sustainable carmaker' in the world according to the Dow Jones Sustainability Indices (DJSI), which is the most significant index for stock investors. The recognition was based on a review of ESG performance of a total of 31 automotive companies based on criteria such as environmental and climate protection strategy, innovation management and corporate social responsibility [24]. After the unfair behavior became known, VW investors suffered heavy losses through the decrease of share prices, and fines and compensation payment claims affects profitability negatively for years.

Statistical analysis shows that none of the differences in the overall CSR rating of the 10 companies together is different from the overall CSR performance of VW at $95 \%$ reliability level, while world automotive industry average is significantly lower than the mean for the 10 European motor vehicle manufacturer in every year from 2011 till 2019.

\subsection{Analysis of the CSR Subcategories at Volkswagen}

The four CSRHub subcategories are Community, Employee, Environment and Governance. Concerning that the underreported emission practice was a greenwashing action, we may expect that the main difference will be shown in the Environment rating of VW before and after the scandal. Results show different pattern, and it is partly explained by the definition of the four subgroups of indicators (Figure 4).

Environment aspect includes company's resource management and its effect on the ecosystem, and practically, pollution prevention programs. Its subcategories are resource management, environmental policy and energy and climate change. Numbers show that environment rating of the company shows slight decrease in the period of 2014-2019, following a relatively high volatility 3-year period. Comparing this trend with the average of the 10 carmakers, we can conclude that very similar trends were realized for the other car manufacturers.

Community category includes the Product subcategory, which "reflects a company's capacity to reduce environmental costs, create new market opportunities through new sustainable technologies or processes, and produce or market goods and services that enhance the health and quality of life for consumers"3. This approach emphasizes the basic role of companies: to serve consumers need on a sustainable way.

3 https://esg.csrhub.com/csrhub-esg-data-schema, retrieved 03 April 2021 


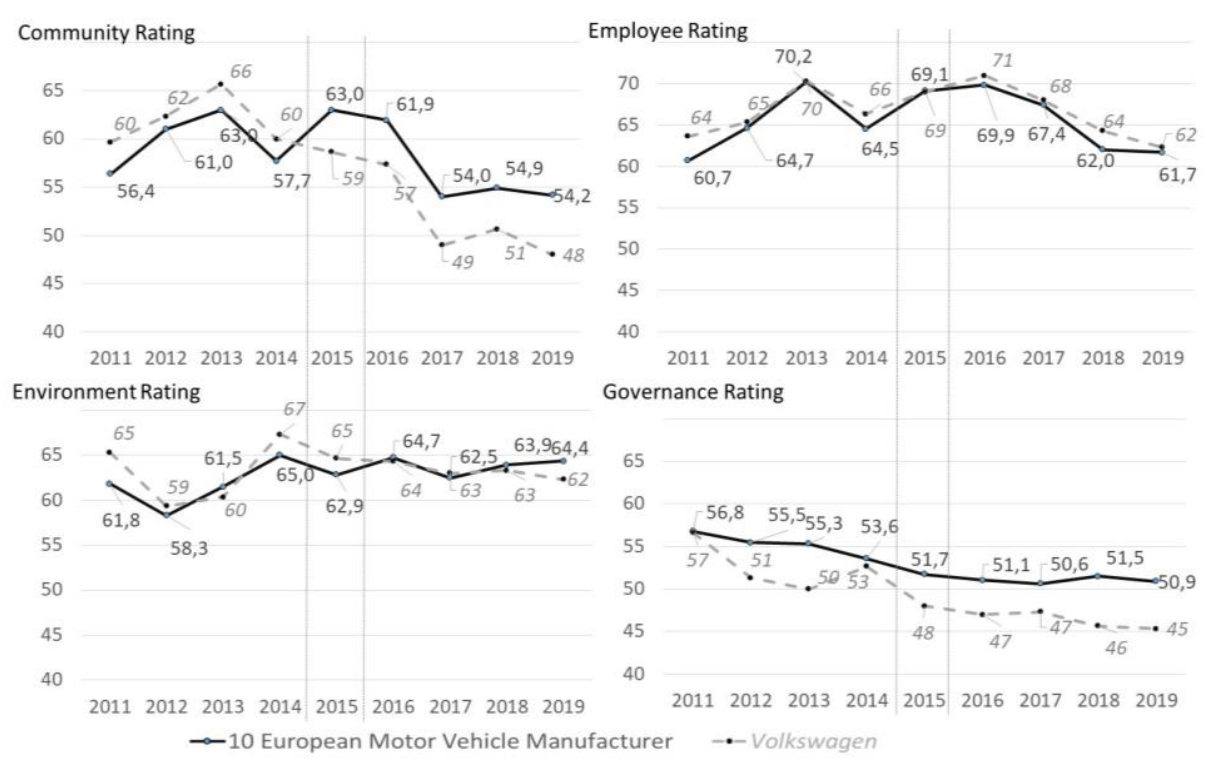

Figure 4

CSR category ratings of Volkswagen and the 10 European motor vehicle manufacturers in the period of 2011-2019

Source: own calculation from CSRHub database

As we have already mentioned at the sample description, child labor issues in the supply chain and political issues (Iran and Burma cases) can be connected to some of the selected carmakers.

The other area where VW's CSR rating is also lagging behind from the average of the 10 companies' is the Governance category. Governance aspect deals with leadership ethics, board composition, transparency and reporting practices. Although the CEO of VW, Martin Winterkorn - who has held this position from 2007 - has resigned following the scandal, he did not acknowledge his responsibility. An additional factor that weakens confidence is the reliability of external audit process of CSR reports. According to the Governance ratings VW's rating in majority of the examined period was below the average of the 10 companies' value.

Employee rating of VW shows no significant difference from the average of the 10 car manufacturers. However, decreasing value of the rating from 2016 reflects to the challenges of the industry. 


\subsection{Analysis of CSR Subcategories at Volkswagen}

Analyzing the differences between the aggregated data of the 10 motor vehicle companies and VW, in 2011 we find statistically significant difference at $\mathrm{p}<0.05$ level only at Product subcategory - in favor of the Volkswagen.

Product rating of VW has changed exactly the opposite direction compared to the average. In the period of 2011-2014, VW's product rating was higher than the average of the selected companies (in 2012 and 2014 the difference was not statistically significant). From 2015-2019 VW's Product rating was significantly lower than the average, and shows a dramatic decrease from 69 (2014) to 45 (2019). The Product rating for the 10 companies also shows a negative trend, but it reached a turning point in 2019.

However, in other relevant dimensions, like Environment Policy and Reporting and also in Energy and Climate Change the VW's rating was visibly higher than the average, and slightly higher at Community Development and Philanthropy, Human Rights and Resource Management dimensions, but differences were not statistically significant.

In 2018, the direction was just the opposite: VW's ratings were worse than the mean of the 10 companies - except the Environment Policy and Reporting subcategory. Only for the Product category evaluation we can say that the difference is statistically significant at $\mathrm{p}<0.05$ level.

At this final step of the analysis, we just focus on the CSR performance of VW and compare it to its former performance (Figure 5). For comparison, we used years 2011 and 2018, especially because goal settings and strategic plans of VW was formulated for the 2008-2018 period, called Strategy 2018. "Our Strategy 2018 focuses on positioning the Volkswagen Group as a global economic and environmental leader among automobile manufacturers. We have defined four goals that are intended to make Volkswagen the most profitable, fascinating and sustainable automaker in the world by 2018" [25]. Second reason for using 2018 instead of 2019 is that we have a complete database for 2018.

Improving performance can be observed only at Compensation \& Benefits subcategory, while CSRHub gave significantly worse ratings to VW at the following subcategories: Board, Leadership \& Ethics, Transparency \& Reporting and Product. Heavy credibility loss is reflected in the significant decrease of Governance sub-categories: trust in the honest communication and ethical behavior of the firm was harmed to a large extent. 


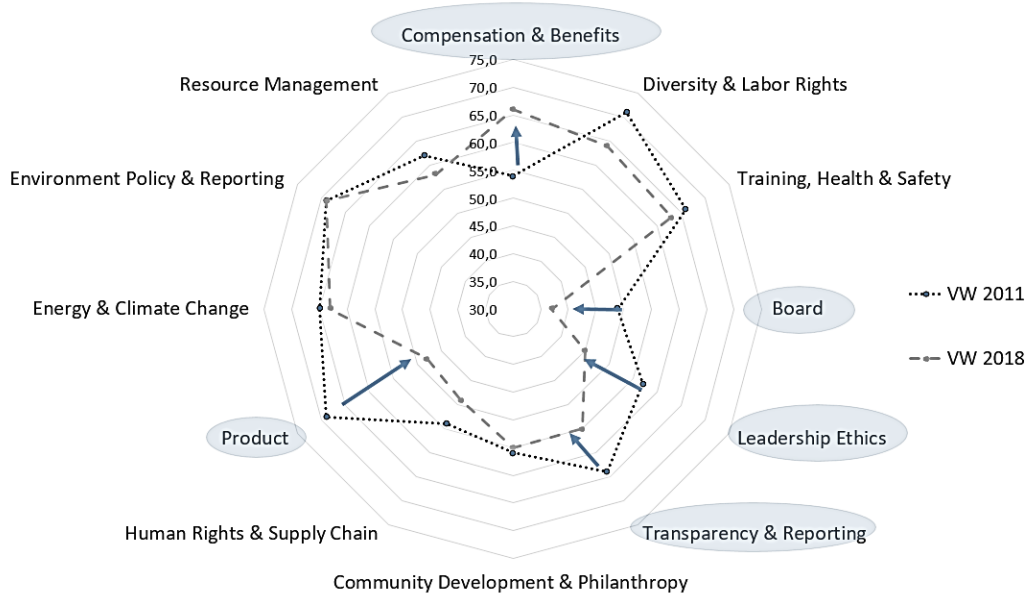

Figure 5

Comparison of CSR subcategory ratings of Volkswagen Group between 2011 and 2018. Arrows and circles show statistically significant difference at $\mathrm{p}<0.05$ level

Source: own calculation from CSRHub database

\section{Discussion}

The VW scandal turned the attention again to the importance of recognizing and preventing greenwashing. The main features of greenwashing activity are: (1) an information disclosure decision, (2) deliberate, (3) initiated by companies, and (4) beneficial to firms and costly to society [26]. All of these features characterized the VW scandal in 2015.

Because of the long-term, misleading, deliberate action of VW, four questions need to be addressed:

(1) Why it seems to be more profitable to create and use technologies which cheat and risk the good reputation of the company than create real greener solutions?

(2) How this event effects the other car-manufacturers situation on the market?

(3) How much consumers and industries should rely on the reports of independent CSR rating companies and indices, and environmental awards?

(4) How the scandal effects the credibility of and future trust toward CSR actions of any company? 
Actually, there were warning signs. VW argued the ambitious emission goals of the EU: the company opposed to the EU's emission target, describing it as not being based on "a realistic appreciation of the costs and technical progress necessary to meet the goal within the timescale. (...) Volkswagen is not only opposed to the $30 \%$ emissions reduction target - the company also argues that the EU's existing $\mathrm{CO}_{2}$ reduction target for new cars sold by 2020 , set at $95 \mathrm{~g} / \mathrm{CO}_{2} / \mathrm{km}$, is too challenging. This target was adopted in 2009 as part of Europe's climate and energy legislation" [27]. That shows that the exaggerating targets may put too much pressure on market players. However, BMW and General Motors were ready to follow the new goals.

Consumers may think, that other carmakers, competitors of VW were aware of the details of the manufacturing process, and the use of the special software, so they should have known about the misleading practice. That had been proven by the investigations started at other carmakers and who had also been found guilty.

Another aspect is that the positive image of automotive firms via their CSR actions in general had a positive attitude toward the industry, so all the actors could have advantage from it. Widely known phenomenon when companies do small steps into the required direction to prevent the stricter legislation on a given issue. So the situation was also favorable for the competitors.

All stakeholder groups - especially external ones - must rely on the communication that is given by the firm or/and they can get information on official institutions (e.g. external audit of CSR reports) and third-party actors (like sustainability indices). These institutions can increase the credibility and trust toward the companies' CSR actions. Although the VW has been removed from the Dow Jones Sustainability Indices in 2015, which was just a necessary step following the emission test manipulation. Nevertheless, it could not detect the problems beforehand - even if Greenpeace published a detailed report in 2011 about "The Dark Side of Volkswagen" [27]. Greenpeace accused VW of exaggerating green record and resisting attempts to make popular models such as the market-leading Golf more fuel efficient. Greenpeace claimed that despite having an image as a family friendly, green brand, VW Group had made less progress on fuel efficiency than rivals such as BMW and Toyota. The report also mentioned that VW was opposing vital climate policies in Europe and was openly against the strong fuel efficiency standards.

The CSR ratings shows that the main sources of the problem were the product features and the lack of real engagement toward a more sustainable operation and product design. Therefore, the results of the analysis could not prove hypothesis 1 : CSR rating of VW has not changed positively - just the opposite happened: overall CSR rating of VW has decreased slightly each following year after the scandal. The depth of the crisis is shown by the fact that not only VW CSR rating declined, but the 10 companies' average too. Despite showing and communicating regret after the scandal, analysis of the detailed ratings of CSR subcategories 
could not support hypothesis 2 . Product dimension (which includes product safety, sustainable technologies, and environmental cost reduction issues) shows significant decrease after the scandal, however rating for Environment category stays the same.

Governance category showed the critical dimension of CSR rating: credibility of management and real ethical standards have been questioned and VW has to fight hard to regain confidence. "In truth, our Company faces a dual challenge. We have not yet surmounted the diesel crisis for which we ourselves are responsible; its consequences will continue to weigh on us for the near future. We have taken significant steps to strengthen our internal processes and control mechanisms and to refocus on compliance and integrity" [28].

\section{Conclusions}

Under the Paris agreement on climate change, the EU committed to cut greenhouse gas emissions by at least $40 \%$ in all economic sectors by 2030 compared to 1990 levels [2]. While sectors like agriculture, energy and residential sector has been showing steps in this direction, transportation still show higher emission level than in 1990. Related to CO2 emissions, the EU has set a goal of reducing emissions from transport by $60 \%$ by 2050 compared to 1990 levels [2]. This ambitious goal cannot be reached without the intensive commitment of European car manufacturers.

The results of our study show that after the VW emission scandal, CSR ratings of big automotive companies show no improvement, but a slight decline - especially in Community related and Governance related issues. As Product subcategory of Community aspect of CSR reflects to the product safety and quality issues, we must mention that more and more cases of car recalls were announced in the last years in the automotive industry.

In 2019, 380 passenger car recalls were announced, which is $32 \%$ more than in the previous year. The number of models affected were also higher by $25 \%$. Compared to 2018, there is an increase in the number of recalls, models affected and brands involved in recalls based on dangerous safety, health and environmental hazards. Most recalls were reported in 2019 by Mercedes-Benz (56), Citroën (25) and Peugeot (23). Volkswagen was also in the top ten with 17 recall cases. ${ }^{5}$ Although the number of sold cars also increased during this period, the growing number of recalls, questions the effectiveness of quality management systems.

Limitations for our study, can be traced back to the limited access of the database, which, in our study, consisted of those car manufacture companies, which had detailed CSR ratings for the examined period of 2011-2019. The other limitation, stems from the fact that we focused on a single event, that received significant

5 https://car-recalls.eu/2019-most-recall-car-europe/, retrieved 4 March, 2020 
media attention, while other events also had positive or negative impact on the firms' CSR policies.

Majláth [29] has already pointed out that the lack of significant consumer boycotts toward VW, after the scandal in 2015 , showed that even consumers themselves were not very much interested in the harmful emission of passenger cars.

Introducing the future perspective of the automotive industry, PWC [30] published its scenarios based on the latest automotive trends. According to this report, collaborations in different forms among carmakers help to share risks and investments needed for designing new solutions. However, both high and delayed investment scenarios into electric vehicles predict lower return on capital, for the entire auto industry.

Accepting the basic theory of marketing - as the main role of the company, is to identify and satisfy the needs of the consumers, in a profitable way - future research should also investigate how the attitude of potential consumers can be changed to a more socially responsible and more critical direction.

VW scandal received high media attention, therefore, its effects are more visible, but, there are other greenwashing actions, which still remain hidden. Discovering them is an extremely important step to a better future. Recently, De Freitas Nettó et al. [31] give a detailed review on greenwashing literature. Their work can summarize 13 different types of greenwashing actions, which shows that over time, various forms of greenwashing have flourished and even expanded. In addition to civil organization activity, institutional actions and more control is needed to filter and expose greenwashing actions more efficiently in the Automotive Industry.

\section{Acknowledgement}

Authors thank to the IUT du Havre and to the EDEHN laboratory for granting access to CSRHub database.

\section{References}

[1] Nasa: "The Causes of Climate Change". climate.nasa.gov. NASA. 2019 https://climate.nasa.gov/causes/

[2] European Parliament: $\mathrm{CO}_{2}$ emissions from cars: facts and figures (infographics); 201 2 https://www.europarl.europa.eu/news/en/headlines/ society/20190313STO31218/co2-emissions-from-cars-facts-and-figuresinfographics

[3] ICCT: New study quantifies the global health impacts of vehicle exhaust, 2019 https://theicct.org/news/health-impacts-transport-sector-pr-20190227 retrieved 2 January 2021

[4] Statista: Europe car sales: share of diesel engines 2013-2017, by country ; Published by Statista Research Department, Jan 31, 2020 
https://www.statista.com/statistics/425113/eu-car-sales-share-of-dieselengines-by-country/

[5] European Commission: Automotive industry, 2019 https://ec.europa.eu/growth/sectors/automotive_en, retrieved 21 March, 2021

[6] EPA (United States Environmental Protection Agency): Learn About Volkswagen Violations, 2016 https://www.epa.gov/vw/learn-aboutvolkswagen-violations, retrieved 2 May, 2019

[7] "Defeat Devices Must Go", The News Herald, - via Newspaperarchive, United Press International, 23 January 1973

[8] Buric, Christian: "Verschärfter ADAC EcoTest: auch Benziner mit zu hohen Feinstaubwerten" [Stronger ADAC EcoTest: also petrol with too high fine particle count]. ADAC (in German). Retrieved 25 March 2017 cited by https://en.wikipedia.org/wiki/Diesel_emissions_scandal\#cite_note7

[9] "The history of the diesel scandal, or the biggest corporate fraud in history" (in Hungarian:" A dízelbotrány története, avagy a történelem legnagyobb céges csalása”) Origo, 3 March 2019, https://www.origo.hu/gazdasag/20190225-vw-dizelbotrany.html retrieved 3 March, 2021

[10] European Commission: A Renewed EU Strategy 2011-14 for Corporate Social Responsibility, 2011, European Commission, Brussels. https://eurlex.europa.eu/legalcontent/EN/TXT/PDF/?uri=CELEX:52011DC0681\&from=EN

[11] Arraiano, I.; Hategan, C. D.: The Stage of Corporate Social Responsibility in EU- CEE Countries European Journal of Sustainable Development, 2019, Vol 8(3):340-353.p.

[12] Freeman, R. E.: Strategic management: a stakeholder approach. 1984, Massachusetts: Pitman

[13] Fraga-Lamas, P.; Fernández-Caramés, T. M.: A review on blockchain technologies for an advanced and cyber-resilient automotive industry, IEEE Access, 2019, 7, 17578-17598.p.

[14] Salzmann, O.; Ionescu-Somers, A.; Steger, U.: The business case for corporate sustainability, Literature review and research options, European Management Journal, 2005, 23 27-36.p.

[15] Dabic, Marina; Painter-Morland, Mollie; Colovic, Ana; Lamotte, Olivier; Brozovic, Silvana: Industry-specific CSR: analysis of 20 years of research, European Business Review, 2016 Vol. 28, No. 3 250-273.p.

[16] Tarabella, Angela; Burchi, Barbara: A Corporate Social Responsibility multidimensional Indicator to Evaluate the Effects on Financial 
Performance of the Chemical Industry Quality Management, 2013 (14) 102-109.p.

[17] Russo Spena, Tiziana; Tregua, Marco; De Chiara, Alessandra: Trends and Drivers in CSR Disclosure: A Focus on Reporting Practices in the Automotive Industry Article (Online only version available) in Journal of Business Ethics, 2018, 151:563-578.p.

[18] Arena, C.; Bozzolan, S.; Michelon, G.: Environmental reporting: Transparency to stakeholders or stakeholders' manipulation? An analysis of disclosure tone and the role of board of directors. Corporate Social Responsibility and Environmental Management, 2014, 22(6), 346-361.p.

[19] Teck, T. P.; Ayadurai, S.; Chua, W.; Sorooshian, S.: Sensemaking Corporate Social Responsibility, Reflexive Organisational Change and Moral Transpose, the Case of Volkswagen 'Diesel Dupe' Crisis Journal of Management and Sustainability, 2020 Vol. 10, No. 1; 66-82.p.

[20] Chauvey, J.; Giordano-Spring, S.; Cho, C. H.; Patten, D. M.: The normativity and legitimacy of CSR disclosure: Evidence from France. Journal of Business Ethics, 2015, Vol. 130(4), 789-803.p.

[21] Pérez-López, D.; Moreno-Romero, A.; Barkemeyer, R.: Exploring the relationship between sustainability reporting and sustainability management practices. Business Strategy and the Environment, 2013, Vol. 24(8), 720734

[22] Bengtsen, P.; Kelly, A.: Vauxhall and BMW among car firms linked to child labor over glittery mica paint; The Guardian, (28 Jul 2016): https://www.theguardian.com/global-development/2016/jul/28/vauxhallbmw-car-firms-linked-child-labour-mica?mod=djemlogistics, retrieved 2 May 2020

[23] "VW emissions 'defeat device' isn't the first", AutoWeek, 24 September 2015, https://www.autoweek.com/news/a1877431/vw-emissions-defeatdevice-isnt-first/ retrieved 2 December, 2020

[24] Hickman, M.: VW named as Europe's least green car maker, Independent, 23 October, $2011 \mathrm{https} / / / \mathrm{www} . i n d e p e n d e n t . c o . u k / c l i m a t e-c h a n g e / n e w s / v w-$ named-as-europe-s-least-green-car-maker-2303655.html, retrieved 2 April, 2021

[25] Volkswagen Annual Report, 2012, https://annualreport2012. volkswagenag.com/managementreport/reportonexpecteddevelopments/strat egy/strategy2018.html, retrieved 2 April, 2021

[26] Bowen, F. J.; Aragon-Correa, A.: Greenwashing in corporate environmentalism research and practice: the importance of what we say and do Collaborative Guest Editorial Organization \& Environment June 2014 Vol. 27, No. 2, 107-112.p. 
[27] Greenpeace: The Dark Side of Volkswagen, 2011 https://issuu.com/gp.nordic/docs/thedarksideofvw, retrieved 2 April, 2020

[28] Volkswagen Sustainability Report, 2017, https://www.volkswagenag.com/presence/nachhaltigkeit/documents/sustain ability-report/2017/Nonfinancial_Report_2017_e.pdf, p. 12

[29] Majláth, M.: How Does Greenwashing Effect the Firm, the Industry and the Society - the Case of the VW Emission Scandal 111-125, In: Reicher, Regina Zsuzsanna (ed.) FIKUSZ 2016 - Symposium for Young Researchers: Celebration of Hungarian Science 2016: Proceedings Budapest, Hungary: Óbuda University (2016) p. 181

[30] Automotive trends (2019) https://www.pwc.com/gx/en/ceo-survey/2019/ Theme-assets/reports/automotive-trends-report.pdf, retrieved 02. April 2021

[31] De Freitas Netto, S. V.; Sobral, M. F. F.; Ribeiro, A. R. B.; Soares, G. R. D. L.: Concepts and forms of greenwashing: a systematic review. Environmental Sciences Europe, 2020. Vol. 32, 19. https://doi.org/10.1186/s12302-020-0300-3 